UDK 314.74(497.11)

Biblid 0543-3657, 72 (2021)

God. LXXII, br. 1183, str. 5-34

Izvorni naučni rad

Primljen: 11.8.2021.

Prihvaćen: 11.10.2021.

doi: https://doi.org/10.18485/iipe_mp.2021.72.1183.1

Aleksandar JAKOVLJEVIĆ

\title{
Effects of Public Policy Measures on Combating Migration Challenges in Serbia ${ }^{2}$
}

\begin{abstract}
The Global Competitiveness Report 2020 ranks Serbia among the countries worst affected by the brain-drain issue globally. It is estimated that approximately 30 to 50 thousand people migrate each year. The research examines the effects of the adopted policy measure and analyses future measures planned for Serbia. The author focuses on the elimination of push factors, reforming sectors of society that are stimulating outward migration and "pull measures", attracting both the diaspora and foreign citizens to reside in Serbia. The author justifies the initial hypothesis that the issue of circular migration requires a comprehensive approach. Reducing the brain drain problem and fostering repatriation require the simultaneous introduction of public policy proposals that target all key pain points and provide effective results in attracting talented people and supporting the long-term development of Serbia.

Keywords: Circular migration, Serbia, foreign policy, graduates, public policy, diaspora.
\end{abstract}

\footnotetext{
${ }^{1}$ Project Assistant, United Nations Development Programme, Belgrade, Serbia. E-mail: aleksandar.jakovljevic@undp.org

${ }^{2}$ The opinions expressed in this publication are those of the author's. They do not purport to reflect the opinions or views of the UNDP. The designations employed in this publication and the presentation of material therein do not imply the expression of any opinion whatsoever on the part of the UNDP concerning the legal status of any country, area or territory or of its authorities, or concerning the delimitation of its frontiers.
} 


\section{Introduction}

Migration to more economically developed countries has long been viewed as a negative trend for countries of emigration. Countries with high immigration reap the benefits by attracting a labour force and knowledgebase expertise, thereby strengthening their economies at the expense of the countries of emigration which tend to be less developed, thus widening the development gap. With the growing reliance on technology, reduction of travel barriers in the last decade and the emergence of remote work due to the COVID-19 pandemic, a more comprehensive approach to migration has emerged. It is centred around the idea that migratory trends can be managed through public policies and other measures to benefit beyond the country of destination, harnessing its development potential for the countries of origin and even for the migrants themselves. ${ }^{3}$ With over 240 million international migrants, it is becoming an increasingly important process which is reshaping economic, political, and cultural contexts around the world. ${ }^{4}$

The focus of this research paper will be to analyse migratory trends in Serbia, compare them to other regional and European countries, and discuss the effects of implemented policies and measures on migration and propose future areas of intervention. Based on available data, the level of contribution of public policies to the changing environment will be evaluated, bearing in mind the broader context and other occurrences which may have contributed to the overall result. The broader international context will be supplemented by examples of major public policy accomplishments in other European countries which serve as the basis for formulating policies in Serbia.

The Global Competitiveness Report 2017-2018 ranks Serbia, alongside BiH and Croatia, as the worst affected by the brain drain globally. ${ }^{5}$ It is estimated that approximately 30 to 50 thousand people migrate each year, mostly to the European Union (EU). ${ }^{6}$ The brain drain affects all sectors of society, and the

\footnotetext{
${ }^{3}$ Ronald Skeldon, "Managing migration for development: Is circular migration the answer?", The Whitehead Journal of Diplomacy and International Relations, vol. 11, 2010, p. 1.

${ }^{4}$ Ronaldo Munck, "Globalisation, Governance and Migration: An Introduction." Third World Quarterly, vol. 29, no. 7, 2008, pp. 1229-1231.

${ }^{5}$ The Global Competitiveness Report 2017-2018, World Economic Forum, Geneva, September 2017, Internet, http://www3.weforum.org/docs/GCR2017-2018/05FullReport/The GlobalCompetitivenessReport2017\%E2\%80\%932018.pdf, 1/6/2021, p. 67; p. 99; p. 257.

${ }^{6}$ Statistics on migration, residence permits, citizenship and asylum for the enlargement countries, Eurostat, Luxembourg, 2020, Internet, https://ec.europa.eu/eurostat/documents/ 4031688/10361659/KS-03-20-002-EN-N.pdf/26f0dc16-4a08-2707-f8d5-8b1b84794169?t $=1578923591000,12 / 7 / 2021$, p. 3 .
} 
migration of young and highly educated individuals diminishes prospects for sustainable growth. According to research published by the Vienna Institute for International Economic Studies, titled "Net Migration and its Skill Composition in the Western Balkan Countries between 2010 and 2019", a different perspective has been presented. The research examines the migratory trends between the Western Balkans and the EU. Available data for Serbia during the period 2015-2019 shows that 222,889 Serbian citizens were granted EU residence permits for the first time. ${ }^{7}$ Net immigration trends, on the other hand, show only 40,000 emigrants, 8,000 individuals annually. ${ }^{8}$ Additionally, Serbia has seen a net positive migration in the age group 25-29 and a positive influx of 90,000 highly skilled individuals and an influx of circa 40,000 individuals with low education. ${ }^{9}$ Such findings do not necessarily contradict the narrative of the Global Competitiveness Report, but rather present a complete picture. In comparison to other observed countries and territories, Serbia has experienced the most substantial reversal of the brain drain phenomenon, with only Montenegro experiencing a modest influx of highly educated individuals.

Additionally, the global COVID-19 pandemic has shifted trends with a growing number of repatriates in Serbia. Empirical evidence of the Returning Point program could lead to the conclusion that the effects of the pandemic have helped attract the diaspora back to Serbia. ${ }^{10,11}$ With the recent emergence of data that supports this claim, the trend merits further analysis and closer observance. The change is supported by the Government of Serbia, which has implemented activities since 2019 aimed at combating the issue of negative migratory trends through circular and economic migration.

\footnotetext{
${ }^{7}$ Sandra Leitner, Net Migration and its Skill Composition in the Western Balkan Countries between 2010 and 2019: Results from a Cohort Approach, WIIW, Vienna, March 2021, Internet, https:// wiiw.ac.at/net-migration-and-its-skill-composition-in-the-westernbalkan-countries-between-2010-and-2019-results-from-a-cohort-approach-p-5682.html, 15/6/2021, p. 37.

${ }^{8}$ Ibid. p. 35.

${ }^{9}$ Ibid. p. 50.

${ }^{10}$ The Returning Point program was established with the support of the government and the United Nations Development Programme (hereinafter UNDP). The program's focus was on promoting circular migration, providing direct assistance to the Serbian diaspora, proposing public policy measures aimed at fostering repatriation and enhancing cooperation with Serbian citizens abroad.

${ }^{11}$ Andrew Higgins, As Vaccinations Speed Along in Serbia, the Country Basks in the Glow of a Successful Campaign, The New York Times, New York, 17 March 2021, Internet, https://www.nytimes.com/2021/03/17/world/europe/as-vaccinations-speed-alongin-serbia-the-country-basks-in-the-glow-of-a-successful-campaign.html, 1/7/2021.
} 


\section{Methods and structure of the paper}

The author has examined the initial hypothesis that the issue of circular migration requires a comprehensive approach which has presented specific policy guidelines. Reducing the negative impacts of the brain drain and fostering repatriation requires the simultaneous introduction of public policies and programs targeting key pain points to attract a skilled workforce back to Serbia. In addition, comparable data has been drawn based on the policies implemented in countries with similar levels of economic development, segmenting this paper into four main parts.

The first segment focuses on the complexity of migration in Serbia and the wider region by elaborating on the phases of migration that have occurred since the 1960s. Current migratory trends have been presented alongside the existing framework assigned to reduce migration, the contribution of the diaspora and the extent of its impact on the economic stability in Serbia. The second segment presents the public policies and other measures implemented since 2019 to reduce emigration and promote immigration of both Serbian and foreign citizens. During the research, the author has focused on the effects of measures taken to diminish push factors that encourage outward migration and pull factors that help attract individuals to Serbia. The third segment deals with the effects of public policy and other measures implemented in Serbia aimed at providing a systematic response to migratory trends and attracting the Serbian diaspora and foreign citizens. Based on available data, this paper aims at analysing and elaborating on the long-term effects of public policy measures.

The global economy provides opportunities for individuals to move more freely between countries and seek more competitive and attractive livelihoods. Some economists opine that we are increasingly living in the age of migration rather than the age of mobility. The fourth segment presents key conclusions and recommendations for improving existing measures and identifies key future areas of intervention. The aim is to present future opportunities and challenges for Serbia in the post-COVID era in the context of growing cross-border mobility.

The research draws its conclusion based on publicly available data from relevant national and international sources, publications of research institutes, think tanks, and other similar sources and, where necessary, empirical evidence from the author's current and prior assignments in migration. It should be observed that precise data on migration in Serbia are scarce, and thus all findings are deduced from different sources and cross-referenced to ensure a high degree of reliability of the conclusions presented herein. 


\section{History of migration, migration framework, and current trends in Serbia}

For centuries, migrations from Serbia have been driven by economic and political factors. The primary factors are attributed to armed conflicts, political instability, and inadequate employment opportunities in the Balkan region. It is possible to identify different stages of migration from Serbia and the Balkan region, and the reasons for emigration. This research paper will observe migration history starting with the wave of migration from the erstwhile SFR Yugoslavia which began in the 1960s. Individuals who migrated during this time and their direct descendants form an important part of the Serbian diaspora and have the potential to be directly influenced by modern public policies aimed at fostering repatriation or cooperation with this group.

This wave began in the mid-60s and was almost exclusively an economic migration. ${ }^{12}$ Between 1965 and 1992, 232,267 Yugoslavs emigrated based on bilateral agreements between Yugoslavia and Western European countries, reaching the peak in 1970. ${ }^{13}$ Based on the estimates of the Federal Office of Employment Affairs, an additional 85,000 individuals left the country during the same time without the assistance of competent authorities. ${ }^{14}$ Among them, 15,000 were highly educated. ${ }^{15}$ The disintegration of Yugoslavia triggered the second wave of emigration. Deteriorating economic conditions, United Nations-imposed sanctions and armed conflicts led thousands of individuals to leave Yugoslavia. ${ }^{16}$ During this time, about 2.3 million people became refugees or were displaced by the conflict. ${ }^{17}$ Many decided to settle in Western Europe and North America. While other former Yugoslav republics saw a greater number of refugees due to the military action, Serbia and Montenegro saw the emergence of migratory trends known as the "brain drain". Research from 1995 shows that $18.5 \%$ of the refugees opted to immigrate to Canada and $10.7 \%$ to the United States of America (US). ${ }^{18}$ Before the outbreak of the civil war, 250

${ }^{12}$ Drenka Vuković, "Migrations of the labour force from Serbia”, SEER: Journal for Labour and Social Affairs in Eastern Europe, Vol. 8, No. 4, 2005, pp.139-150.

${ }^{13}$ Ibid.

${ }^{14}$ Ibid.

${ }^{15}$ Ibid.

${ }^{16}$ Corrado Bonifazi, Marija Mamolo, „Past and Current Trends of Balkan Migrations “, in Espace populations sociétés, vol. 2004/3, University of Lille 1, 2004, pp. 519-531.

${ }^{17}$ Henry Kamm, "Yugoslav Refugee Crisis Europe's Worst Since 40's“, The New York Times, 24 July 1992, Section A, p. 1.

${ }^{18}$ Grečič, V, V. Matejic, D. Kutlaca and O. Mikic, Migracije visokostručnih kadrova i naučnika iz SR Jugoslavije, Savezno ministarstvo za razvoj, nauku i životnu sredinu, Institut za medunarodnu politiku i privredu, Beograd, 1996, str. 40. 
highly skilled workers migrated annually from the FR Yugoslavia, while in 1993 alone, the US accepted 422 highly skilled workers and Canada issued 1,750 immigration visas to highly educated individuals. ${ }^{19,20}$

The third wave of emigration began with the democratic transition of Serbia in the year 2000 and has been an ongoing process. The latest wave is characterized by individuals seeking to pursue education abroad. The alignment of Serbia with the acquis communautaire caused a shift in migratory flows, with 69.2\% of migrants immigrating to Germany and Austria in 2016 alone, and almost $90 \%$ to the EU and Switzerland. ${ }^{21}$ The continuous emigration from Serbia has led to a sizeable diaspora. Based on the 2008 estimate of the International Organization for Migration, the size of the Serbian diaspora reached almost 4 million. ${ }^{22}$

\section{Diaspora contribution}

The size of the Serbian diaspora, which is about $55 \%$ of the total population of Serbia, carries vast development potential. Diaspora engagement with the country of origin is not new, yet modalities and levels of cooperation differ based on cultural, political, and other contexts. ${ }^{23}$ In the case of Serbia, the contribution of the diaspora is most widely seen through foreign remittances.

Remittances in Serbia form an important source of income for local citizens and the economy. The diaspora contribution through remittances peaked in 2018, with 4.32 billion USD being sent to Serbia through formal and informal channels. ${ }^{24}$ Remittances accounted for $8.78 \%$ of the gross domestic product (GDP) in 2018, which was slightly higher than the total

${ }^{19}$ Drenka Vuković, "Migrations of the labour force from Serbia”, op. cit. p. 142.

${ }^{20}$ FR Yugoslavia was formed after the dissolution of SFR Yugoslavia and included two former republics, Serbia and Montenegro.

${ }^{21}$ Mr Rade Ćirić, Tomislav Despić, Marija Suzić, Nenad Jevtović, Troškovi emigracije mladih, Institute for Development and Innovation, Belgrade, January 2021, Internet, https://drive.google.com/file/d/1_DUnI-RNims0ZMdmON5G0VEVNI-B-62y/view, 22/6/2021, p.9.

${ }^{22}$ Sheila Siar, Migration in Serbia: A Country Profile 2008, International Organization for Migration, Geneva, 2008, Internet, https://publications.iom.int/system/files/pdf/ serbia_profile2008.pdf, 22/6/2021, p. 11.

${ }^{23}$ Dovelyn Rannveig Agunias, Kathleen Newland, Developing a Road Map for Engaging Diasporas in Development, International Orgnaization for Migration \& Migration Policy Institute, Geneva, 2012, p. 13.

${ }^{24}$ World Bank, Personal remittances, received (current US\$) - Serbia, The World Bank Group, Washington DC, 2019, Internet, https:// data.worldbank.org/indicator/BX.TRF.PWKR.

10 CD.DT?locations=RS, 20/6/2021. 
stock of foreign direct investment (FDI) during the same year, only to fall to $7.3 \%$ in $2020 .{ }^{25,26}$ While both the World Bank and the National Bank of Serbia track remittances, the former tracks both formal and informal channels, while the latter tracks only formal channels of remittance. The level of remittances is shown in Graph 1 below.

Graph 1: Remittances towards the Republic of Serbia 2007-2019, USD billions

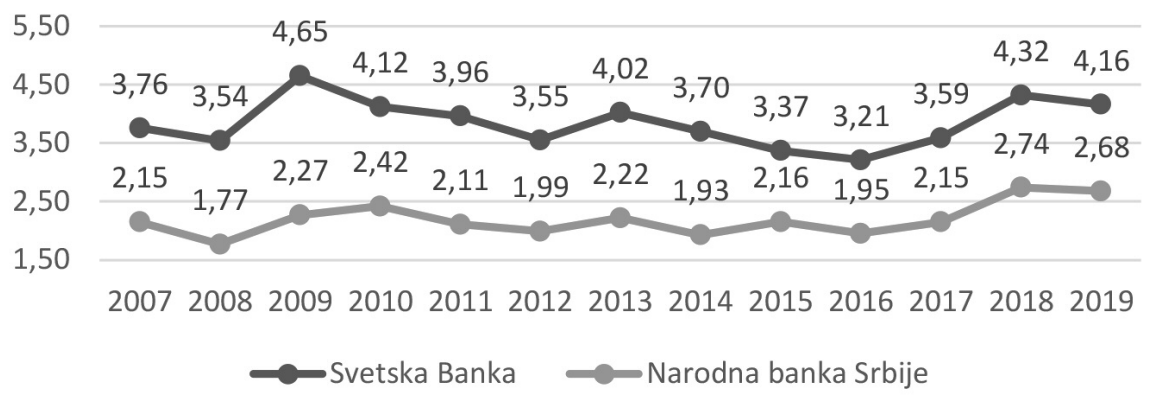

Source: National Bank of Serbia, 2021; and World Bank, 2021.

While observing the broader region, we could witness a relatively high reliance on remittances both in the EU and non-EU members. The EU members, such as Bulgaria, Romania, Poland and Hungary, have all converged to the value of remittances between $1 \%$ and $3 \%$ of their GDP. ${ }^{27}$ On the other hand, migratory trends in Croatia, in the past ten years, have increased its reliance on remittances. In 2007, remittances to Croatia accounted for $3.7 \%$ of GDP, later increasing to a record $7.1 \%$ in $2020 .{ }^{28}$ Croatia almost levelled with Serbia in 2020, while other non-EU countries are experiencing larger dependence on remittances, accounting for $12.5 \%$ in Montenegro, 9.9\% in Albania, and 9.1\% in Bosnia and Herzegovina. ${ }^{29}$

Remittance flows remained strong even during the COVID-19 pandemic. Based on the World Bank's Migration and Development Brief,

\footnotetext{
${ }^{25}$ World Bank, Foreign direct investment, net inflows (BoP, current US\$) - Serbia, The World Bank Group, Washington DC, 2019, Internet, https://data.worldbank.org/indicator/ BX.KLT.DINV.CD.WD?locations=RS, 20/6/2021.

${ }^{26}$ World Bank, Personal remittances, received (\% of GDP) - Serbia, The World Bank Group, Washington DC, 2019, Internet, https:// data.worldbank.org/indicator/BX.TRF.PWKR. DT.GD.ZS?locations=RS, 20/6/2021.

${ }^{27}$ Ibid.

${ }^{28}$ Ibid.

${ }^{29}$ Ibid.
} 
the level of remittances decreased by $8.7 \%$ to 3.87 billion USD. ${ }^{30}$ This is above the initial estimates, which expected a drop of about $20 \%$. While observing this data, it is important to observe the claim made by the government that 300 to 400 thousand diaspora members returned to Serbia in March due to COVID-19. ${ }^{31}$ Their expenditures and bank withdrawals in Serbia were classified as consumption instead of remittances, which could lead to the conclusion that the drop could even be lower.

Nonetheless, remittances need to be managed efficiently and not used solely as a source for increased consumption among the local population and for reducing balance of payments deficits. ${ }^{32}$ The structure of remittances in Serbia does not support long-term investments and harnesses its development potential. With $70 \%$ of total remittances in consumption and $26 \%$ in real estate, only $3 \%$ is directed toward long-term investments. ${ }^{33}$ Such a structure supports the living standards of individuals but does not allow for long-term developmental effects.

The inflow of foreign pensions to senior repatriates to Serbia presents another steady stream of monthly diaspora contributions. About 60-65 thousand recipients of foreign pensions in Serbia contributed monthly EUR 20 million in 2009. ${ }^{34}$ During the COVID-19 pandemic, the Ministry of Labor published that 240,118 citizens receive a pension from abroad, with no economic data available to analyse further the economic impact of this contribution. ${ }^{35}$

${ }^{30}$ Ibid.

${ }^{31}$ Branko Vučković, U Srbiju se vratili zbog pandemije, šta dalje, Radio Free Europe, 22. April 2020, internet, https://www.slobodnaevropa.org/a/u-srbiju-se-vratili-zbog-pandemijesta-dalje/30570817.html, 25/7/2021.

${ }^{32}$ Alida Vračić, The Way Back: Brain Drain and Prosperity in the Western Balkans, European Council on Foreign Relations, May 2018, p. 14.

${ }^{33}$ Mr Rade Ćirić, Tomislav Despić, Marija Suzić, Nenad Jevtović, Troškovi emigracije mladih, op. cit. p. 37.

${ }^{34}$ Dr Branko Vasiljević, Influence of Remittances on Economic and Social Development in Serbia, University of Belgrade, Belgrade, 2009, Internet, http://test.fpn.bg.ac.rs/wpcontent/uploads/2010/05/11-Prof.-dr-Branko-Vasiljevi\%C4\%87-Uticaj-doznaka-naekonomski-i-socijalni-razvoj-u-srbiji.pdf, 1/7/2021, p. 206 .

${ }^{35}$ Ministry of Labor, Employment, Veteran and Social Affairs, Isplata inostranih penzija za državljane Srbije nastavlja se i tokom vanrednog stanja, Ministry of Labor, Employment, Veteran and Social Affairs, Belgrade, $27^{\text {th }}$ March 2020, Internet, https://www.minrzs. gov.rs/sr/aktuelnosti/vesti/isplata-inostranih-penzija-za-drzavljane-srbije-nastavlja-se-

12 i-tokom-vanrednog-stanja, 15/6/2021. 


\section{The institutional framework for migration in Serbia}

Harnessing the potential of the diaspora and managing migrations require a broad institutional framework to enable the effective implementation of public policies. It is known that the diaspora can bring back financial, social, and intellectual capital and foster the development processes of their country of origin. ${ }^{36}$ It requires an effective institutional framework, through an inclusive environment involving stakeholders from the government, private and civil sectors, and the international community.

The Serbian diaspora is of significant size and is very heterogeneous. Different phases of migration caused by varied political, economic, and social circumstances have caused a divergence of interest amongst the group and its relations towards institutions in Serbia. ${ }^{37}$ From the Returning Point experience, Serbian emigrants are eager to contribute towards helping the Serbian government, while others consider it the main cause for emigration. The latter are interested in transferring knowledge or capital back to Serbia in their personal capacity, rather than providing direct assistance to the government and its agencies.

The current institutional framework for migration and the Serbian diaspora is complex and decentralized. In 2009, the Law on the Diaspora and Serbs in the Region was adopted, providing the legal framework for a meaningful engagement with the diaspora. ${ }^{38}$ The Ministry of Diaspora was thereby established, and later transformed to the Office for Cooperation with the Diaspora and Serbs in the Region, and was tasked to implement this law and to coordinate activities pertaining to the matter. It approaches the diaspora in a more institutional manner by providing financial assistance to organizations abroad, protecting the rights of the diaspora abroad and cooperating on a bilateral level with key destination countries. ${ }^{39}$ Together with the diplomatic-consular network of Serbia, it assists them in exercising their rights in Serbia, such as the right to vote during parliamentary elections. The Government of Serbia has received feedback from the diaspora that the existing framework has not been sufficient for fostering the repatriation of highly skilled individuals. A more comprehensive approach that could stimulate their contribution and/or repatriation was

${ }^{36}$ Dovelyn Rannveig Agunias, Kathleen Newland, Developing a Road Map for Engaging Diasporas in Development, op. cit. p. 26.

${ }^{37}$ Drenka Vuković, "Migrations of the labour force from Serbia”, op. cit. pp. 142 - 149.

38 "Law on Diaspora and Serbs in the Region", Official Gazette of the Republic of Serbia 88/09, $28^{\text {th }}$ October 2009.

${ }^{39}$ Office for Cooperation with the Diaspora and Serbs in the Region, About Us, Internet, https://www.dijaspora.gov.rs/o-nama/,1/7/2021. 
suggested. It has been observed that the government may not always be the most suitable channel for the mobilization of diaspora resources. ${ }^{40}$ Following input from diaspora organizations, the Office of the Prime Minister organized the first "Talent Meetup" in 2018 aimed at gathering highly skilled and successful diaspora members. It was observed that to achieve better engagement, it would be necessary to consult diaspora members on formulating goals. Two reputable organizations, Serbian Entrepreneurs from San Francisco and the Serbian City Club from London, jointly formulated a proposal for the Prime Minister. The solution was to create a quasi-governmental institution. It would enable contributions from diaspora organizations and blur the distinction between non-governmental and governmental bodies. The program was named the Returning Point and was established to address circular migration under the auspices of the United Nations Development Programme (UNDP).

The Returning Point was established to offer a different approach to migration, one focused more on the mobility of people and a growing reliance on technology. ${ }^{41}$ It focuses on providing support for the repatriation of highly skilled diaspora and fostering cooperation. The goal was to provide a comprehensive approach to initiating policy changes aimed at improving the diaspora status and diaspora repatriation, support and handholding in the repatriation of highly skilled diaspora, informing the diaspora on opportunities in Serbia, and broad communication on promoting circular migration. With one of the world's fastest shrinking populations, the Returning Point team addressed some of the issues identified by their colleagues at the UNDP Accelerator Lab Serbia. ${ }^{42}$ In June 2021, Forbes magazine, in an interview with the Prime Minister of Serbia, called the Returning Point a concierge service for Serbians interested in returning. ${ }^{43}$ Currently, the Returning Point is the key driver in initiating and implementing public policy changes pertaining to the diaspora. It has been

${ }^{40}$ Dovelyn Rannveig Agunias, Kathleen Newland, Developing a Road Map for Engaging Diasporas in Development, op. cit. p. 32.

${ }^{41}$ Irena Cerović, Depopulacija: o čemu se u stvari radi?, UNDP Serbia, $31^{\text {st }}$ December 2019, internet, https://www.rs.undp.org/content/serbia/sr/home/blog/2019/depopulation - whats-it-all-about-.html, 24/7/2021.

${ }^{42}$ Francine Pickup, U Srbiji se pojavljuje nov pristup korišćenju talenata i hvatanju u koštac sa depopulacijom, UNDP Serbia, $16^{\text {th }}$ March 2020, internet, https://sdgintegration. undp.org/serbia-new-approaches-tap-talent-and-tackle-depopulation, 24/7/2021.

${ }^{43}$ Robert C. Wolcott, National Digital Transformation: A Conversation With Serbia's Prime Minister Ana Brnabic, Forbes Magazine, $15^{\text {th }}$ June 2021, Internet, https://www-forbescom.cdn.ampproject.org/c/s/www.forbes.com/sites/robertwolcott/2021/06/15/natio nal-digital-transformation-a-conversation-with-serbias-prime-minister-ana14 brnabic/amp/, 20/6/2021. 
able to implement several key public policy changes and is currently spearheading several initiatives aimed at attracting individuals of Serbian origin, digital nomads, and others. Migration and the diaspora also fall under the authority of the Ministry of Labor, Employment, Veteran and Social Affairs, which has adopted the Strategy for Economic Migrations 2021-2027 and is coordinating its implementation. ${ }^{44}$ The Commissariat for Refugees and Migration is predominantly tasked with coordinating activities pertaining to refugees, asylum seekers, and others.

Finally, other institutions in Serbia are contributing to the topic of diaspora and migration through supportive roles or by focusing on a specific objective. The Serbian Chamber of Commerce has established the Diaspora Business Council to bolster diaspora investment. The Ministry of Youth has established the Young Talent Fund, which supports Serbian students abroad to the tune of EUR 2.5 million. The Science Fund of the Republic of Serbia has an open call for cooperation between local and diaspora scientists while the main source of data is provided by the Statistical Office of the Republic of Serbia. Currently, no similar initiatives are being implemented in the region. Despite a similar migratory challenge in other former Yugoslav republics, the Returning Point is the sole example of a body that deals directly with the highly skilled diaspora. In 2008, through a private initiative, an organization called "Tuk Tam" was established in Bulgaria. ${ }^{45}$ As a grassroots movement, it aimed to help "welleducated young professionals find their way back to or stay connected with the home country". Ever since, they have assisted 14,000 people in their career paths in Bulgaria, provided 100,000 people with insights into Bulgaria and gathered 80,000 EUR in scholarships.

\section{Current migratory trends}

Prior to the evaluation of current migratory trends, it is important to note that there is a limited amount of official data which would enable detailed analysis. The Statistical Office currently tracks only internal migrations within Serbia and has plans to collect official data for international migrations in the years to come. In the absence of official data, estimates pertaining to international migrations rely on data from countries of destination and available cross-referenced data fragments.

${ }_{44}$ "Strategy on Economic Migration", Official Gazette of the Republic of Serbia 21/20, $6^{\text {th }}$ March 2020.

${ }^{45}$ Тук-там Initiative, Bulgaria, Internet source: https://tuk-tam.bg/join?gclid=CjwKCA jw9aiIBhA1EiwAJ_GTSoB0cQSVDQQ57whcPhgXHa_z4Z01h9Fq8BCwrUhSeInTp4ysev uKuBoCexMQAvD_BwE, 2/7/2021. 
Nonetheless, publicly available data claim that 30 to 50 thousand individuals leave Serbia annually. Such data is not official, yet it falls within the ballpark estimate provided by the Organization for Economic Cooperation and Development (OECD) International Migration Outlook. To generate some relevant analysis and generate meaningful conclusions, the ministry without a portfolio in charge of Demography and Population Policy issued a publication titled "Student Migrations" in $2018 .{ }^{46} \mathrm{It}$ interviewed 11,000 students to receive a respectable statistical sample for further analysis. $32.4 \%$ of interviewed students planned on emigrating from Serbia upon the completion of their studies, with the number reaching above $36 \%$ for students in information technology and medicine. ${ }^{47}$ Out of 1,700 medical students enrolled annually, the Serbian Medical Chamber reports that the country has been experiencing an increased annual rate of 800 doctors emigrating. ${ }^{48}$ The Institute for Research and Innovation estimates that the relevant cost of education of a single doctor is EUR $55,000 .{ }^{49}$ With the related lost investment of EUR 44 million, the brain drain of doctors is the best example of the wider problems Serbia is facing. Emigration of doctors only exacerbates the issue as it speeds up the emigration of other people in need of a stable healthcare system and is detrimental to the long-term prospects for development. The primary reason for their desire to migrate is either the inability to find a job in the professional area $(27.3 \%)$ or lower earnings $(21.3 \%) .{ }^{50}$ Other countries in the region are faced with similar problems. ${ }^{51}$

Contrary to popular opinion, Croatian accession to the EU has only exacerbated migratory trends, as seen in Graph $2 .{ }^{52}$

${ }^{46}$ Prof. dr Slavica Djukić Dejanović, Gordana Bjelobrk, Nikola Jovanović, Ljiljana Djordjević, Migracije studenata, Office of the Minister without Portfolio in charge of Demography and Population Policies, 2018.

${ }^{47}$ Ibid, pp 25-26.

${ }^{48}$ Beta, Politika, Politika: Godišnje iz Srbije odlazi 800 lekara, N1, Belgrade, November 2018, Internet, https:/ / rs.n1info.com/zdravlje/a434932-politika-godisnje-iz-srbije-odlazi-800lekara/, 2/7/2021.

${ }^{49}$ Mr Rade Ćirić, Tomislav Despić, Marija Suzić, Nenad Jevtović, Troškovi emigracije mladih, op. cit. p. 21.

${ }^{50}$ Mr Rade Ćirić, Tomislav Despić, Marija Suzić, Nenad Jevtović, Troškovi emigracije mladih, op. cit. p. 17.

${ }^{51}$ Sandra Leitner, Net Migration and its Skill Composition in the Western Balkan Countries between 2010 and 2019: Results from a Cohort Approach, op. cit. 1.

$16{ }^{52}$ Alida Vračić, The Way Back: Brain Drain and Prosperity in the Western Balkans, op. cit. 7. 
Graph 2: Emigration from Croatia

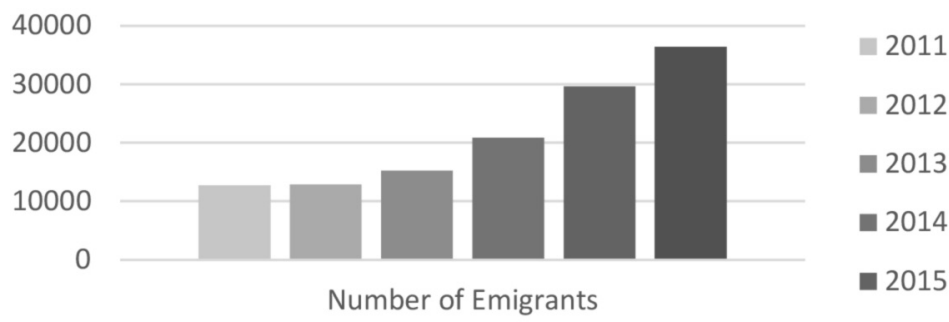

Source: Alida Vračić, 2018:7.

Unlike Croatia, Serbia may not experience a similar phenomenon. EU countries, mainly Germany, have substantially eased requirements for Serbian workers to emigrate..$^{53}$ Since the introduction of the new immigration law in Germany, from March 2020 until the end of the year, a total of 30.200 visas were issued. Out of those, Serbian citizens were issued 2.024 visas, more than any of the countries included. ${ }^{54}$ This has enabled migratory flows as if Serbia were an EU member state. Therefore, it will not experience a sudden liberalization of regulation which has led to the increase in emigration from Croatia.

Despite the trends which generally tend to support the notion of emigration from the Balkans, positive signs have recently emerged. The data presented above, and generally used in public discussions, focus solely on outward migration. Therefore, to fully understand migratory trends in Serbia, it is necessary to discuss net migrations. An internal memorandum to the Returning Point by the Agency for Qualification, which oversees the foreign diploma recognition process, has noted 1,030 approved requests for recognized foreign university diplomas in 2020. As the recognition of diplomas is not necessary for employment in the private sector, hence the number of repatriates could be substantially larger. Additionally, according to the Migration Profile of Serbia in the year 2019, 15,554 individuals were naturalized while 11,119 individuals were granted Temporary Residence permits for the first time with a majority requesting it for the purpose of

${ }^{53}$ Sabine Kinkartz, Germany's new labor immigration law explained, Deutsche Welle, $1^{\text {st }}$ March 2020, internet, https://www.dw.com/en/germanys-new-labor-immigration-lawexplained/a-52575915, 22/7/2021.

${ }^{54}$ Germany Visa, 50,000 German Visas Have Been Issued to Third-Country Citizens Under the Skilled Workers Immigration Act, $11^{\text {th }}$ June 2021, internet, https://www.schengenvisa info.com/news/germany-has-issued-over-50000-visas-through-the-skilled-workersimmigration-act-so-far, 23/7/2021. 
employment. ${ }^{55}$ This information sheds a different light on a prevailing negative sentiment towards migration.

Another significant study, published in March 2021 by the Vienna Institute for International Economic Studies, revealed a positive upward trend in Serbian migration. Observing the migration from 2010 to 2019, the research focused on migratory trends based on age and education. Due to methodological adjustments, some data for Serbia is shown only for the period 2015-2019. During that time, Serbia had a negative net migration of 40,000 individuals to the EU, averaging 8,000 individuals per year. If we consider the OECD data from 2016 that show that around $90 \%$ of migrants from Serbia emigrate to the EU, we can estimate that the net negative migration towards the entire world could average 9,000.56 This is in stark contrast to the narrative of Serbia losing 30 to 50 thousand people annually. During 2015-2019, Serbia also attracted 90,000 highly educated individuals, 40,000 low-educated individuals, while losing a net 170,000 individuals with mid-level education, arguably the most favourable statistics in the Western Balkans, as shown in Graph 3.

Graph 3 (left) and Graph 4 (right): Serbia - cumulative net migration flows by educational attainment level 2015 - 2019 and Cumulative net migration flows by cohort in Serbia
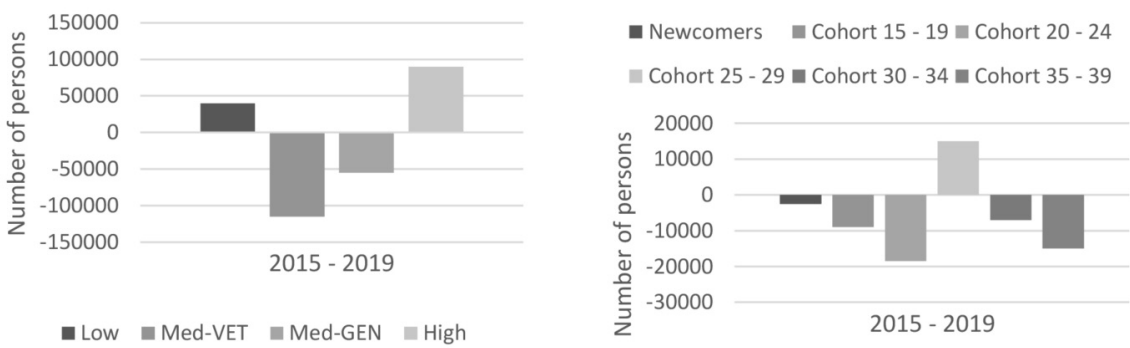

Source: Sandra Leitner, 2021.

Serbia has had a positive influx in the 25-29 age group, which correlates with the repatriation of students upon completion of their education abroad (Graph 4). This age group is also the most fertile, which is of particular significance due to the ageing population and diminishing birth rates.

${ }^{55}$ Government of the Republic of Serbia, Migration Profile of the Republic of Serbia for 2019, Commissariat for Refugees and Migration, Belgrade, 2020, Internet, https:/ / kirs.gov.rs/ media/uploads/Migracije/Publikacije/Migracioni_profil_Republike_Srbi.\%20godinu.p df, $1 / 7 / 2021$, p. 8 .

${ }^{56}$ Rade Ćirić, Tomislav Despić, Marija Suzić, Nenad Jevtović, Troškovi emigracije mladih, op. 18 cit. p. 9. 
Recently, the first post-COVID migration data have been published, using alternative data sources. The Bootstrappers, a team from Harvard University, have developed a regression model to determine the size and movement of Serbian ex-pats using Facebook data and their IP addresses, and cross-referencing them with official statistics in countries of origin to ensure a high level of reliability. ${ }^{57}$ Based on the model, in October 2020, approximately 860,000 individuals were estimated to have originated from Serbia but had spent at least 6 weeks abroad at the moment of data measuring. ${ }^{58}$ In February 2021, this number decreased to 811,000, with the latest measurement from May 2021 showing 735,000 abroad. ${ }^{59} \mathrm{~A}$ decrease of 125,000 is attributed to the repatriation to Serbia. Their project has won first place as part of the UNDP Data Challenge supporting the creation of new public policies as a response to depopulation challenges. The subsequent wave of repatriation, for the first time quantified by the Bootstrappers team, is evidence of the post-COVID migration trends. Increased repatriation, as observed by the Returning Point team, is supported by the alternative data sources, and substantiates the claim that the COVID-19 pandemic has shifted migratory trends towards repatriation to the country of origin.

\section{Public policies and other implemented measures in Serbia}

All published information used for the purpose of presenting the current migratory trends have not considered the changes due to the COVID-19 pandemic. The COVID-19 pandemic has the potential to influence not only the size but also the composition of migrants. ${ }^{60}$ The Returning Point has had around 6,000 enquiries in the year 2020 from the diaspora asking questions regarding repatriation, with the trend continuing in 2021. The COVID-19 pandemic has opened a new opportunity to influence migratory flows. It is observed that several individuals came back to their countries of origin upon the outbreak of the pandemic. ${ }^{61}$ The key question is how the government's approach towards public policies can ride this wave of growing repatriation and focus on bringing individuals with intellectual, social, and financial

${ }^{57}$ Aleksandar Bauranov, Tica Lin, Leveraging Social Networks To Track Migration, United Nations Development Programme, Belgrade, 2021, Internet, https://measuringdepopulation.org/emigration-overview.html, 10/7/2021.

${ }^{58}$ Ibid.

${ }^{59}$ Ibid.

${ }^{60}$ Tarchi Dario, Sermi Francesco; McMahon Simon; Kalantaryan Sona; Belmonte Martina; Urso Giuliana, Atlas of Migration - 2020, Publications Office of the European Union, Luxembourg, 2020, pp. 450-452.

${ }^{61}$ Ibid. 
capital to contribute to the overall growth of the Serbian economy. Since 2018, the Government of Serbia has adopted several measures aimed at reducing emigration and fostering repatriation to Serbia. The focus of the measures has been to reduce the desire to emigrate, thus reducing the "pull factors" of the countries of destination, and, more importantly, to work on "push factors" by way of promoting repatriation and cooperation between the diaspora and Serbia and by attracting foreign citizens to move to Serbia.

\section{Adopted and Implemented Public Policies}

During the last several decades, the diploma recognition system has been considered a major obstacle. Despite private companies rarely requiring their employees to undergo a formal recognition process, it remained a symbol of the government's reluctance to attract the diaspora back to Serbia. In 2018, the government adopted a new law for the recognition of foreign academic credentials. ${ }^{62}$ The Law on the National Qualifications Framework established the Agency for Qualifications, which introduced a digital procedure for recognizing foreign university diplomas. The process has been simplified and the deadline for recognizing diplomas has been reduced to 30 days or 8 days for universities on the Academic Ranking of World Universities, the so-called "Shanghai list". The change was a welcoming signal from the government and the beginning of a more proactive attitude toward attracting the diaspora back. Another important piece of legislation has been the introduction of incentives for employing repatriates or foreigners. The beginning of 2020 saw the introduction of two incentive programs. Repatriates under 40 years of age who have lived abroad for longer than 12 months were eligible for a $70 \%$ deduction in taxes and benefits for 5 years if their salary was double the average salary ${ }^{63}$ The second program has no age limit and is aimed at both the diaspora and foreign citizens who were abroad for at least 24 months. They were also eligible for a $70 \%$ deduction in taxes if their salary was triple the average. The incentives came into force on January 1,2020, while the accompanying bylaws came into force in November 2020 due to the pandemic and consequent lockdowns. ${ }^{64}$ At the "Talent Meetup" in 2018, the Prime Minister

62 "The Law on the National Qualifications Framework", Official Gazette of the Republic of Serbia 27/18 \& 6/20, 24 th January 2021.

${ }^{63}$ Serbia Creates, Vodič kroz mere podrške razvoju inovativne privrede, Government of the Republic of Serbia, Belgrade, 2020, Internet, https://serbiacreates.rs/extfile/mere _podrske_inovacijama.pdf, 3/7/2021.

64 "Pravilnik o načinu ostvarivanja prava na umanjenje osnovice poreza na zarade za novonastanjenog obveznika", Official Gazette of the Republic of Serbia 137/20, 13 ${ }^{\text {th }}$ November 202020. 
of Serbia engaged Serbian talented individuals from abroad in a discussion on their problems and on means to foster repatriation. One of the identified problems pertained to the customs regulation allowing for EUR 5,000 of goods to be brought in customs-free, while goods above the threshold were subject to a fee. Based on the diaspora's initiative, the government has brought forward a Decree on Customs Privileges which has raised the limit to EUR 20,000 for those living abroad between 2 to 10 years and eliminated the barrier for all individuals living longer than 10 years abroad. The Decree came into force in late 2019. ${ }^{65}$ Data from the Migration Profile of the Republic of Serbia in 2019 has shown that the primary purpose for foreign citizens requesting Temporary Residency in Serbia was employment. In 2019, 69.6\% of applicants wanted to come to Serbia for work purposes, a significant jump from $44.7 \%$ in $2018 .{ }^{66}$ The number of people requesting Temporary Residency for the first time jumped 46\%, from 7,591 to 11,119, with the main countries of origin being the People's Republic of China, the Russian Federation, Turkey, and Ukraine, with no data on the educational structure of the migrants. Interestingly, $88 \%$ of the applicants were male, which could support the claim that they have been employed on infrastructure projects in Serbia. ${ }^{67}$

To increase further the inflow of foreign citizens and highly educated individuals, the Government of Serbia has adopted a Decree establishing a fast-track procedure for granting Temporary Residency to three categories of foreigners. ${ }^{68}$ It established "Start-up Visa" for establishing innovative start-ups in Serbia, "Investor Visa" for investing EUR 50,000 or more into an existing innovative company and "Talent Visa" for individuals with a university degree. The Decree came into force on February 21,2021, two weeks before the first recorded case of COVID-19 and less than a month before the introduction of the State of Emergency and Martial Law.

Combating the problem of migration requires a comprehensive approach. Therefore, public policies aimed at fostering inward migration require a broader environment that attracts people from abroad back to

65 “Uredba o carinskim povlasticama”, Official Gazette of the Republic of Serbia 138/19 \& 86/19, $6^{\text {th }}$ December 2020.

${ }^{66}$ Government of the Republic of Serbia, Migration Profile of the Republic of Serbia for 2019, op. cit., p. 9.

${ }^{67}$ Government of the Republic of Serbia, Migration Profile of the Republic of Serbia for 2019, op. cit., p. 10.

68 “Uredba o kriterijumima za određivanje kategorija stranaca i kateogorijama stranaca kojima se privremeni boravak u Republici Srbiji može odobriti nezavisno od osnova za odobrenje privremenog boravka", Official Gazette of the Republic of Serbia 13/20, $14^{\text {th }}$ February 2020. 
Serbia. Positive economic trends in Serbia could substantiate the data presented in the Migration Profile and the overall impression of the Returning Point Program. According to the World Bank data, Serbia has been growing steadily during the past decade. With the negative GDP growth rate of $1 \%$ during the COVID-19 pandemic, Serbia has shown resilience partly due to the large share of agriculture in GDP and a growing focus on the IT sector. ${ }^{69}$ Over the past decade, Serbia has shown improvement in the environment for doing business in Serbia and in the economic situation. GDP levels have been growing despite the severe floods in 2014 and COVID-19 in 2020 impacting growth rates (Graph 5).

Graph 5: Serbia GDP growth rate: 2012-2021 (left) and

Graph 6: Unemployment rate Serbia: 2014-2021 (right)
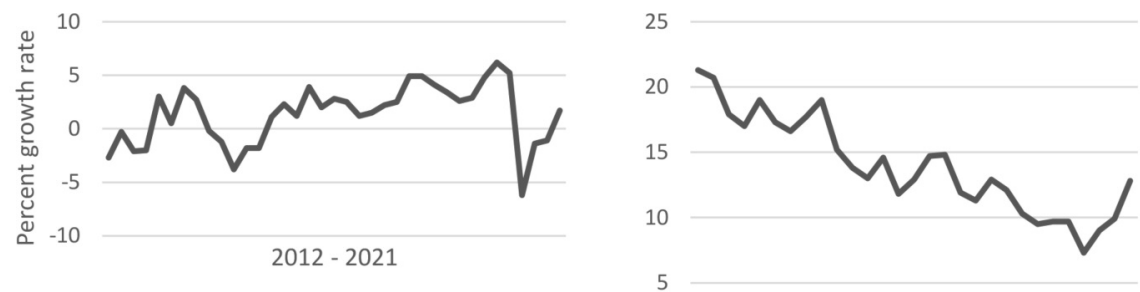

Source: Statistical Office of the Republic of Serbia, 2021.

This growth in economic activity is also accompanied by a decline in the unemployment rate, which has fallen under 10\% in Q3 of 2019 for the first time in the last 20 years (Graph 6). Finally, the ease of doing business, measured by the World Bank's Doing Business report, has shown a continuous improvement in this aspect of Serbian society (Graph 7).

${ }^{69}$ World Bank, Global Economic Prospects, The World Bank Group, Washington DC, June 2021, Internet, https:/ / www.worldbank.org/en/publication/global-economic-prospects, $224 / 7 / 2021$, p. 71. 
Graph 7: World Bank Doing Business Ranking Serbia

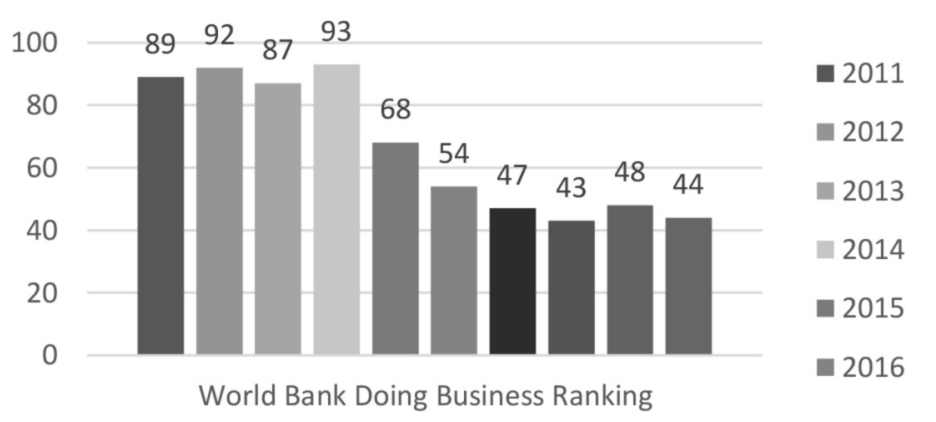

Source: World Bank Doing Business Report, 2011-2020.

The transition towards a more digital lifestyle during the COVID-19 pandemic was beneficial to the Serbian IT industry, with the export of IT services reaching an all-time high of EUR 1,326 billion in 2020, an increase of $4.5 \%$ from the previous year. ${ }^{70}$ Currently, Serbia is facing a shortage of labour force in the IT industry, with some organizations estimating a deficit of 20,000 people..$^{71}$ For that reason, the Office for IT and eGovernment has been continuously organizing educational seminars in IT through which more than 2,200 individuals have received formal skills in IT.72

Digitalization of Serbian society, led primarily by the Office of the Prime Minister and the Office for IT and eGovernment, has contributed to the digital transformation of Serbia. ${ }^{73}$ The government has recognized digitalization as the main catalyst for innovation, modernization, and economic growth. Digitalization processes were supported by international donors such as the UNDP, the European Investment Bank, and others. A Register of Civil Records, generating an electronic registry of all citizens, was created, while many public policies were adopted to enable the digital economy and electronic administrative procedures.

In July 2021, the Returning Point assisted its partners, the UNDP, DSI, StartIT, Nova Iskra, and Share Foundation, in launching a global campaign

${ }^{70}$ Платни биланс Републике Србије, 2007-2020, Народна банка Републике Србије, Ингтернет: https://nbs.rs/sr/drugi-nivo-navigacije/statistika/platni_bilans, 3/7/2021.

${ }^{71}$ Tanjug, IT sektor obara rekorde: Srbiji nedostaje 20.000 inženjera, B92, Belgrade, December 2019, Internet, https:/ / www.b92.net/biz/vesti/srbija.php?yyyy=2019\&mm=12\&dd= 03\&nav_id=1625811,3/7/2021.

${ }^{72}$ Prekvalifikacije za IT sektor Budućnost je stigla, Vlada Republike Srbije, Kancelarija za informacione tehnologije i elektronsku upravu, Internet: https://www.ite.gov.rs/ tekst/sr/117/prekvalifikacije-za-it-sektor.php, 4/7/2021.

${ }^{73}$ Goran Pitić, Nebojša Savić, Srđan Verbić, "Digital Transformation and Serbia", Ekonomika preduzé́a, vol 66, no 1-2, pp. 116-117. 
aimed at digital nomads. BelgradeGets.digital is a campaign aimed at attracting digital nomads to work remotely in Serbia with the offering of a free COVID-19 vaccine. Its goal is to attract 2,000 individuals who will discover Belgrade and promote its potential in IT and remote work throughout the world. The implemented measures have been comprehensive, enabling support for repatriation and cooperation through all aspects of life, targeting particularly those who have the potential to contribute the most to the economy. In the absence of credible data up to this point and considering a major global shift due to the COVID-19 pandemic, it cannot be determined to what extent have the implemented public policies effectively contributed to the changing trend observed by the use of alternate data and the Returning Point empirical experience. It is the author's conviction that with proper promotional activities, the true effects will be visible in the subsequent years. It will further reduce the net emigration and potentially level it in this decade.

To cater for the needs of the diaspora, the Office of Prime Minister has established the Returning Point program, as explained in this paper. It was tasked to implement other measures which would provide direct assistance to the diaspora and serve as the primary contact point for Serbian and foreign citizens who want to move to Serbia. The mission of the program is to be in direct contact with the diaspora and implement activities in a modern and innovative manner. During 2020, it received over 6,000 inquiries from people from abroad. Based on the enquiries, the Program has prepared a digital product named Guides for Repatriates, which are semipersonalized products providing relevant business, personal, and administrative information to prospective repatriates. It further assisted in a hand-holding process, directing high-profile individuals toward potential employers, and assisting in overcoming bureaucratic and other barriers to investment in Serbia. During the State of the Emergency, the Returning Point was tasked to coordinate repatriation flights to Serbia which brought back almost 12,000 people. Together with the Ministry of Foreign Affairs, it provided support to students and pupils from abroad and organized flights back to Serbia. With the success of the vaccination campaign in Serbia, the Returning Point has organized a diaspora vaccination campaign that saw the arrival of over 550 individuals from abroad to receive the vaccine. The activities of the organization are accompanied by a communication campaign that focuses on promoting the benefits of circular migration. Through weekly podcasts and media presence, the Program aims to break the general narrative that repatriation is a sign of failure abroad.

In addition to public policy measures, the government of Serbia has enabled other programs which are contributing to a more competitive environment for repatriates. To diminish the attractiveness of foreign 
markets for medical workers, primarily Germany, the government has organized an employment program for top medical students in Serbia. The program is seen as a preventive measure for migration toward Germany and other attractive markets. In the past three years, the Ministry of Health claims to have employed over 400 top medical students and 700 nurses, and a total of 25,000 medical workers since the year $2014 .{ }^{74}$

The year 2021 has seen important developments in housing loans for the diaspora. For the first time, commercial banks have been allowed by the National Bank of Serbia to issue housing loans to non-resident citizens and foreigners. With the estimated annual inflow of capital for real estate accounting for USD 1.1 billion, enabling housing loans could present an important tool for economic development. It should stimulate further diaspora investments in Serbia and create tangible bonds with Serbia, fostering repatriation as well.

\section{Future initiatives}

The Serbian diaspora has been previously described as complex in terms of its motivation for emigration, yet it is complex due to its origin as well. The Law on Diaspora, Article 2, defines the diaspora as both citizens of the Republic of Serbia as well as Serbian emigrants from Serbia and the region, and their descendants. ${ }^{75}$ Due to historical and political changes in the region, many Serbs are not citizens of the Republic of Serbia, yet they fall under the category of diaspora. Due to their cultural ties to Serbia, they do not consider themselves foreigners in Serbia, even though they de jure are foreign citizens. The Constitution mandates the government to protect Serbs (Article 13, Section 2), regardless of their citizenship, thus granting them a different status from other foreign citizens. ${ }^{76}$

Public policies and other implemented activities have been centred around attracting citizens of the Republic of Serbia and foreigners to come to Serbia. They have, de jure, allowed Serbs holding citizenship of other countries to use the benefits, although it has not provided a special status for them. Therefore, we observe an opportunity for the government of Serbia to provide preferential treatment to them. In 2007, Poland introduced

\footnotetext{
${ }^{74}$ Ivana Božović, Posao za 100 najboljih diplomaca medicinskih fakulteta, Radio Television of Serbia, Belgrade, $17^{\text {th }}$ June 2021, Internet, https://www.rts.rs/page/stories/sr/story /125/drustvo/4414815/srbija-medicinski-fakultet-diplomci-posao.html, 1/7/2021.

75 "Law on Diaspora and Serbs in the Region", Official Gazette of the Republic of Serbia 88/09, $28^{\text {th }}$ October 2009.

76 "Constitution of the Republic of Serbia", Official Gazette of the Republic of Serbia 98/06, $10^{\text {th }}$ November 2006.
} 
a program of quasi-citizenship called Karta Polaka, attracting people of Polish descent to Poland and giving them the right to live, work, and study. ${ }^{77}$ Its primary focus was on Poles living in other countries after the dissolution of the Soviet Union. Over 200,000 quasi-citizenships have been granted so far, helping many Poles return to Poland and enjoy a similar status as Polish citizens. Such an approach should be considered by Serbia as well, in line with its regulatory environment and legal practice. It should allow for Serbs, regardless of their citizenship, to come and settle in Serbia. Due to cultural ties, Serbs from abroad would potentially assimilate quite easily into Serbian society, thus limiting cultural shock.

Other initiatives were recognized during writing this research paper pertaining to the regulatory environment and actions taken by the government to encourage repatriation. In 2008, the Government of Serbia established the Young Talents Fund to support talented young people in Serbia. Among other programs, they sponsor around 500 students to study abroad, providing them with a stipend of EUR 5,000. Despite the requirement to return upon the completion of studies, the effects of such a program have never been officially evaluated, while unofficially they can be deemed unsatisfactory. With EUR 2.5 million spent annually, the government should undertake detailed scrutiny of the success of the program and evaluate if a more effective structure should be created to support a smaller number of talented individuals with a more substantial reward.

Finally, to intensify the positive trend towards repatriation, the Government of Serbia together with its partners should strive to carry on with regulatory reforms. Easing of regulations pertaining to repatriation should be a key goal to allow for an effortless process. During our work at the Returning Point, the team has identified two issues that present an opportunity for reform. For repatriates coming from outside the EU/EEA area, the current regulation forbids the registration of motor vehicles due to the incompatibility of certificates. It presents an obvious obstacle to repatriation. Croatia and Bulgaria have allowed exceptions to the rule once applied to their nationals repatriating, and a similar approach should be observed by Serbia. Finally, the introduced customs incentives have allowed only citizens living abroad for work purposes to make use of it. Due to the strict Customs Law, students and others living abroad for non-work-related reasons are not incentivized to return. Current measures should be continuously observed and reviewed to encourage further repatriation and open Serbia to foreign citizens who wish to settle and build their future in the country.

${ }^{77}$ Zvezda Vankova, Circular Migration and the Rights of Migrant Workers in Central and Eastern Europe, Springer International Publishing, Cham, Switzerland, 2020, pp. 114-116. 


\section{Conclusion}

Migration in the Balkans has long been considered a negative trend fueled by high unemployment and weak institutions. ${ }^{78}$ Both in Serbia and the broader region, emigration to Western Europe has been an ongoing process. Nonetheless, Serbia is the first country in the region to show reverse and positive trends. In the period from 2010 to 2019, it has been the only country that has had a net influx of people, both highly educated and those with low education. Despite the overall negative net migration fueled by the migration of high-school-educated individuals, it remains a promising sign. The conclusions of the Vienna Institute for Internal Economic Studies point out the reverse trend among students from Serbia as well. They have concluded that a growing percentage of students who migrate from Serbia to study abroad are returning upon completion of their studies. ${ }^{79}$ Their return in growing numbers is supported by the data that the age group 1519 is seeing a large net emigration abroad, while the age group of 25-29 is seeing net immigration, especially those with high education. Net immigration of highly educated individuals also carries a broader regional component, as Serbia has positioned itself economically to attract over 8,000 students from Montenegro and Bosnia and Herzegovina. Announcements of deeper economic integration in the Balkans through the EU accession process and the Open Balkan initiative, spearheaded by Serbia, Albania, and North Macedonia, could provide an additional economic impulse that could attract additional university graduates to develop their careers in Serbia.

This positive shift in the trend has occurred in the years prior to the outbreak of the COVID-19 pandemic. While no official data is available, based on the experience and direct communication with the diaspora, COVID-19 is presumed to have a positive impact on migratory trends. Using alternate data sources, an estimated 125,000 people have been repatriated months after the initial introduction of restrictive measures in the world. Based on the methodology developed by the team, from October 2020 until May 2021, 14.5\% of ex-pats returned to Serbia. ${ }^{80}$

According to the statements made by the heads of the Government of Serbia, in the weeks prior to the introduction of the State of Emergency in Serbia, 300 to 400 thousand people returned. Even though it is safe to

${ }^{78}$ Čeperković Marko, Gaub Florence, Donika Emini, Zoran Nechev, Isidora Stakić, Megatrends in the Western Balkans, European Union Institute for Security Studies (EUISS), 2018, Internet, https://www.jstor.org/stable/resrep21139.5?seq=1\#metadata_info_ tab_contents, 6/7/2021, p. 1.

${ }^{79}$ Sandra Leitner, Net Migration and its Skill Composition in the Western Balkan Countries between 2010 and 2019: Results from a Cohort Approach, op. cit. 10.

${ }^{80}$ Aleksandar Bauranov, Tica Lin, Leveraging Social Networks To Track Migration, op. cit. 
assume that many have gone abroad as soon as the situation calmed down, we should observe these occurrences as a trigger for a changing trend.

Observed changes should also not be viewed in the light of the adopted public policy changes which led to the inconclusive assessment of the stated hypothesis. With most changes adopted in late 2019 and 2020, there has not been sufficient time to produce effects observed by the report covering 2010 to 2019. Nonetheless, it represents a valuable policy tool for further improvement of migratory trends in Serbia and increased attractiveness for both the Serbian diaspora and foreigners. At this moment, the authorities are yet to publish official data on the effects of the policies. Full implementation of the measures was presumed to occur in 2020, but due to the pandemic, it is possible that the results do not reveal their true value.

With the concluded migration from Serbia accounting for a negative net of 8 to 10 thousand people, every individual who repatriates due to the implemented measures and direct assistance is reducing the negative migration even further. Therefore, every couple of hundred individuals presents a significant improvement and change for a relatively small country like Serbia. For example, tax incentives for employing repatriates and foreigners were adopted in late 2019 with the bylaws being implemented in Q4 of 2020 due to the pandemic. Program Serbia Creates, in collaboration with the Returning Point, has organized virtual workshops to educate over 350 employers, accountants, and diaspora members about the program's benefits. The response has been promising, with over a thousand enquiries and views sent to the organizers.

Incentives for attracting foreigners to start a business, invest or work in Serbia, came into force a few weeks before the declaration of the State of Emergency in Serbia, thus preventing any promotional activities. With the easing of travel restrictions, it is possible to promote Serbia through the Belgradegets.digital and other initiatives.

In addition to public policies, there are positive signs in the adoption of other measures. The Returning Point Program has assisted over 6,000 individuals in 2020 alone, helping them repatriate or cooperate with Serbia. The campaign to vaccinate the diaspora has included 550 individuals who received assistance from their native country, breaking the narrative that Serbia reaches out for remittances only. In the last decade, Serbia has shown economic progress which has fostered repatriation and attracted foreigners. Net immigration of highly educated individuals also carries a broader regional component, as Serbia has attracted over 8,000 students from Montenegro and $\mathrm{BiH}$. Announcements of deeper economic integration in the Balkans, through the Open Balkan initiative, spearheaded by Serbia, Albania, and North Macedonia, could provide for an additional economic impulse that could attract additional university graduates to develop their 
careers in Serbia. Further details on the Open Balkan initiative remain to be publicly announced. At this moment, the presidents of the three countries have expressed their hope to eliminate physical borders before 2023 and to jointly work on the removal of other barriers to trade and investment.

The pandemic has had a positive effect and has brought back many more people, with a growing reliance on alternate data to substantiate the claim. Combined with the direct fiscal support and support of the Returning Point and similar initiatives, the framework has been created to promote further repatriation. Future successes depend on the proper and continuous financing of the above-mentioned programs, as the failures of such programs worldwide are often associated with the lack of funding. ${ }^{81}$ Further positive results will depend on the continued improvement of key economic factors, improvements in the rule of law, combating corruption, and the European integration process.

To maximize the effects of future policies and activities, stakeholders in Serbia need to identify priority groups for further focus. With several different groups of migrants who have different needs and motivations, the government needs to identify those who carry the biggest development potential and implement clearly focused policies. In the author's view, young people and the highly educated carry the greatest economic and demographic potential and should thus be viewed as a priority group.

\section{Bibliography}

"Law on the National Qualifications Framework", Official Gazette of the Republic of Serbia 27/18 \& 6/20, 24th January 2021.

"Constitution of the Republic of Serbia", Official Gazette of the Republic of Serbia 98/06, 10th November 2006.

"Law on Diaspora and Serbs in the Region", Official Gazette of the Republic of Serbia 88/09, 28th October 2009.

"Pravilnik o načinu ostvarivanja prava na umanjenje osnovice poreza na zarade za novonastanjenog obveznika", Official Gazette of the Republic of Serbia 137/20, 13th November 2020.

"Strategy on Economic Migrations", Official Gazette of the Republic of Serbia 21/20, 6th March 2020.

"Uredba o carinskim povlasticama", Official Gazette of the Republic of Serbia 138/19 \& 86/19, 6th December 2020.

${ }^{81}$ Michael Fullilove, World Wide Webs: Diasporas and the International System, Lowy Institute for International Policy, 2008, p. 70. 
“Uredba o kriterijumima za određivanje kategorija stranaca i kateogorijama stranaca kojima se privremeni boravak u Republici Srbiji može odobriti nezavisno od osnova za odobrenje privremenog boravka", Official Gazette of the Republic of Serbia 13/20, 14th February 2020.

Aguniad Dovelyn Rannveig, Newland Kathleen, Developing a Road Map for Engaging Diasporas in Development, International Orgnaization for Migration \& Migration Policy Institute, Geneva, 2012, p. 13, p. 26, p. 32, p.27, p.41.

Bauranov Aleksandar,Lin Tica, Leveraging Social Networks To Track Migration, United Nations Development Programme, Belgrade, 2021, Internet, https:/ / measuring-depopulation.org/emigration-overview.html, 10/7/2021.

Beta, Politika, Politika: Godišnje iz Srbije odlazi 800 lekara, N1, Belgrade, November 2018, Internet, https://rs.n1info.com/zdravlje/a434932politika-godisnje-iz-srbije-odlazi-800-lekara/, 2/7/2021.

Bonifazi Corrado, Mamolo Marija, „Past and Current Trends of Balkan Migrations ", in Espace populations sociétés, vol. 2004/3, University of Lille 1, 2004, pp. 519-531.

Božović Ivana, Posao za 100 najboljih diplomaca medicinskih fakulteta, Radio Television of Serbia, Belgrade, 17th June 2021, Internet, https://www.rts.rs/page/stories/sr/story/125/drustvo/4414815/srbi ja-medicinski-fakultet-diplomci-posao.html, 1/7/2021ž.

Cerović Irena, Depopulacija: o čemu se u stvari radi?, UNDP Serbia, 31 ${ }^{\text {st }}$ December 2019, internet, https://www.rs.undp.org/content/serbia/ sr/home/blog/2019/depopulation - whats-it-all-about-.html, 24/7/2021.

Čeperković Marko, Gaub Florence, Donika Emini, Nechev Zoran, Stakić Isidora, Megatrends in the Western Balkans, European Union Institute for Security Studies (EUISS), 2018, Internet, https:/ /www.jstor.org/ stable/resrep21139.5?seq=1\#metadata_info_tab_contents, 6/7/2021, p. 1.

Ćirić Rade Mr, Despić Tomislav, Suzić Marija, Jevtović Nenad, Troškovi emigracije mladih, Institute for Development and Innovation, Belgrade, January 2021, Internet, https://drive.google.com/file/d/1_DUnIRNims0ZMdmON5G0VEVNI-B-62y/view ,22/6/2021, p.9, p.37, p. 17, p. 21.

Fullilove Michael, World Wide Webs: Diasporas and the International System, Lowy Institute for International Policy, 2008, p. 70.

Germany Visa, 50,000 German Visas Have Been Issued to Third-Country Citizens Under the Skilled Workers Immigration Act, $11^{\text {th }}$ June 2021, internet, https://www.schengenvisainfo.com/news/germany-has-issued-over- 
50000-visas-through-the-skilled-workers-immigration-act-so-far, 23/7/2021.

Government of the Republic of Serbia, Migration Profile of the Republic of Serbia for 2019, Commissariat for Refugees and Migration, Belgrade, 2020, Internet, https://kirs.gov.rs/media/uploads/Migracije/Publikacije/ Migracioni_profil_Republike_Srbi.\%20godinu.pdf, 1/7/2021, pp. 8-10.

Grečič, Vladimir et al., Migracije visokostručnih kadrova i naučnika iz SR Jugoslavije, Savezno ministarstvo za razvoj, nauku i životnu sredinu, Institut za međunarodnu politiku i privredu, Beograd, 1996.

Higgins Andrew, As Vaccinations Speed Along in Serbia, the Country Basks in the Glow of a Successful Campaign, The New York Times, New York, 17 March 2021, Internet, https://www.nytimes.com/2021/03/17/world /europe/as-vaccinations-speed-along-in-serbia-the-country-basks-inthe-glow-of-a-successful-campaign.html, 1/7/2021.

https://nbs.rs/sr/drugi-nivo-navigacije/statistika/platni_bilans/.

https://www.ite.gov.rs/tekst/sr/117/ prekvalifikacije-za-it-sektor.php.

Kamm Henry, "Yugoslav Refugee Crisis Europe's Worst Since 40's“, The New York Times, 24 July 1992, Section A, p.1.

Kinkartz Sabine, Germany's new labor immigration law explained, Deutsche Welle, 1st March 2020, internet, https://www.dw.com/en/ germanys-new-labor-immigration-law-explained/a-52575915, 22/7/2021.

Leitner Sandra, Net Migration and its Skill Composition in the Western Balkan Countries between 2010 and 2019: Results from a Cohort Approach, WIIW, Vienna, March 2021, Internet, https://wiiw.ac.at/net-migration-andits-skill-composition-in-the-western-balkan-countries-between-2010and-2019-results-from-a-cohort-approach-p-5682.html, 15/6/2021, p.37, p. 35, p. 50, p. 1, p. 10.

Ministry of Labor, Employment, Veteran and Social Affairs, Isplata inostranih penzija za državljane Srbije nastavlja se i tokom vanrednog stanja, Ministry of Labor, Employment, Veteran and Social Affairs, Belgrade, 27th March 2020, Internet, https://www.minrzs.gov.rs/sr/ aktuelnosti/vesti/isplata-inostranih-penzija-za-drzavljane-srbijenastavlja-se-i-tokom-vanrednog-stanja, 15/6/2021.

Munck Ronaldo, "Globalisation, Governance and Migration: An Introduction." Third World Quarterly, vol. 29, no. 7, 2008, pp. 1229-1231.

Office for Cooperation with the Diaspora and Serbs in the Region, About Us,Internet, https://www.dijaspora.gov.rs/o-nama/,1/7/2021.

Pickup Francine, U Srbiji se pojavljuje nov pristup korišćenju talenata i hvatanju $u$ koštac sa depopulacijom, UNDP Serbia, $16^{\text {th }}$ March 2020, internet, 
https://sdgintegration.undp.org/serbia-new-approaches-tap-talentand-tackle-depopulation, 24/7/2021.

Pitić Goran, Savić Nebojša, Verbić Srđan, "Digital Transformation and Serbia", Ekonomika preduzeća, vol 66, no 1-2, pp. 116-117.

Prof. Dr Dejanović Đukić Slavica, mr Bjelobrk Gordana, Jovanović Nikola, mr Djordjević Ljiljan, Migracije studenata, Office of the Minister without Portfolio in charge of Demography and Population Policies, 2018.

Serbia Creates, Vodič kroz mere podrške razvoju inovativne privrede, Government of the Republic of Serbia, Belgrade, 2020, Internet, https:/ / serbiacreates.rs/extfile/mere_podrske_inovacijama.pdf, 3/7/2021.

Siar Sheila, Migration in Serbia: A Country Profile 2008, International Organization for Migration, Geneva, 2008, Internet, https://publications.iom.int/system/files/pdf/serbia_profile2008.pdf, 22/6/2021, p. 11.

Skeldon Ronald, „Managing migration for development: Is circular migration the answer?", The Whitehead Journal of Diplomacy and International Relations, vol 11, 2010, pp. 1.

Statistics on migration, residence permits, citizenship and asylum for the enlargement countries, Eurostat, Luxembourg, 2020, Internet, https:/ /ec. europa.eu/eurostat/documents/4031688/10361659/KS-03-20-002-ENN.pdf/26f0dc16-4a08-2707-f8d5-8b1b84794169? $t=1578923591000$, 12/7/2021, p. 3.

Tanjug, IT sektor obara rekorde: Srbiji nedostaje 20.000 inženjera, B92, Belgrade, December 2019, Internet, https://www.b92.net/biz/vesti/ srbija.php?yyyy=2019\&mm=12\&dd=03\&nav_id=1625811,3/7/2021.

Tarchi Dario, Francesco Sermi, McMahon Simon; Kalantaryan Sona; Belmonte Martina; Urso Giuliana, Atlas of Migration - 2020, Publications Office of the European Union, Luxembourg, 2020, pp. 450-452.

The Global Competitiveness Report 2017-2018, World Economic Forum, Geneva, September 2017, Internet, http://www3.weforum.org/docs /GCR2017-2018/05FullReport/TheGlobalCompetitivenessReport2017 \%E2\%80\%932018.pdf, 1/6/2021, p. 67; p. 99; p. 257.

Vankova Zvezda, Circular Migration and the Rights of Migrant Workers in Central and Eastern Europe, Springer International Publishing, Cham, Switzerland, 2020, pp. 114-116.

Vasiljević Branko Dr, Influence of Remittances on Economic and Social Development in Serbia, University of Belgrade, Belgrade, 2009, Internet, http:/ / test.fpn.bg.ac.rs/wp-content/uploads/2010/05/11-Prof.-drBranko-Vasiljevi\% C4\%87-Uticaj-doznaka-na-ekonomski-i-socijalnirazvoj-u-srbiji.pdf, 1/7/2021, p. 206. 
Vračić Alida, The Way Back: Brain Drain and Prosperity in the Western Balkans, European Council on Foreign Relations, May 2018, p. 14, p. 7.

Vučković Branko, U Srbiju se vratili zbog pandemije, šta dalje, Radio Free Europe, 22. April 2020, internet, https://www.slobodnaevropa.org/a/ u-srbiju-se-vratili-zbog-pandemije-sta-dalje/30570817.html, 25/7/2021.

Vuković Drenka, "Migrations of the labour force from Serbia", SEER: Journal for Labour and Social Affairs in Eastern Europe, Vol. 8, No. 4, 2005, pp. 139150.

Wolcott C. Robert, National Digital Transformation: A Conversation With Serbia's Prime Minister Ana Brnabic, Forbes Magazine, 15th June 2021, Internet, https://www-forbes-com.cdn.ampproject.org/c/s/www. forbes.com/sites/robertwolcott/2021/06/15/national-digitaltransformation-a-conversation-with-serbias-prime-minister-anabrnabic/amp/,20/6/2021.

World Bank, Foreign direct investment, net inflows (BoP, current US\$) Serbia, The World Bank Group, Washington DC, 2019, Internet, https:/ / data.worldbank.org/indicator/BX.KLT.DINV.CD.WD?locatio ns=RS, 20/6/2021.

World Bank, Global Economic Prospects, The World Bank Group, Washington DC, June 2021, Internet, https:/ / www.worldbank.org/en/ publication/global-economic-prospects, 4/7/2021, p. 71.

World Bank, Personal remittances, received (\% of GDP) - Serbia, The World Bank Group, Washington DC, 2019, Internet, https:/ data.worldbank. org/indicator/BX.TRF.PWKR.DT.GD.ZS?locations=RS, 20/6/2021.

World Bank, Personal remittances, received (current US\$) - Serbia, The World Bank Group, Washington DC, 2019, Internet, https:/ / data.world bank.org/indicator/BX.TRF.PWKR.CD.DT?locations=RS, 20/6/2021. 


\section{EFEKTI MERA JAVNE POLITIKE U BORBI PROTIV IZAZOVA DEPOPULACIJE U SRBIJI}

\section{SAŽETAK}

“Global Competitiveness Report 2020" rangira Srbiju kao jednu od zemalja najviše pogođenih fenomenom odliva mozgova sa procenom da godišnje Srbiju napušta 30 do 50 hiljada ljudi. Istraživanje je usmereno na analizu efekata usvojenih javnih politika kao i na analizu budućih planiranih mera. Autor se fokusira na reformu faktora koji podstiču emigraciju, „push factors" kao i na predlaganje javnih politika koji podstiču privlačenje dijaspore, kao i stranih državljana, da borave u Srbiji. Autor podržava hipotezu da pitanje cirkularnih migracija zahteva sveobuhvatan pristup. Ublažavanje fenomena i efekata odliva mozgova, i podržava povratku, zahteva paralelno uvođenje mera javnih politika koje su usmerene kao eliminaciji svih identifikovanih regulatornih prepreka kao i uvođenje efikasnih mera koje će dovesti do privlačenja talenata i dugoročnog razvoja Srbije.

Ključne reči: Cirkularne migracije, Srbija, spoljna politika, diplomci, javne politike, dijaspora. 